\title{
DIFFERENTIATED MARKETING POLICIES IN TERMS OF COMPANY SIZE AND SECTOR DURING GLOBAL RECESSION
}

\author{
A. Kazım KiRTiş \\ Filiz KARAHAN \\ Çanakkale Onsekiz Mart University, Turkey
}

\begin{abstract}
The main aim of this study is to investigate whether perceptions of marketing managers of and responses to the global recession differentiated among the companies in terms of the company size and sector. It is clear from the former literature that both consumers and companies change their perceptions, attitudes and behaviours during economic hardship. In this research, it was searched what the meaning of current economic situation after the 2009 global recession to marketing decision makers is, what the effect of the present economic conditions on marketing decisions is, what kind of arrangements marketing decision makers are doing and how all these perceptions and activities differ according to the company size and sector. In the study, totally 95 firms were surveyed, including 30 large industry firms, 30 large service firms and 35 small firms. According to the results of the surveys, there are some significant differences between large industry and large service firms as well as small firms and large industry firms in terms of their responses to the current economic situations after 2009 global economic crisis while their perceptions of crisis and the impact of the crisis on their companies does not differentiated according to their size and sector.
\end{abstract}

Keywords: Global recession, marketing policies, company size, sector.

\section{INTRODUCTION}

The last global economic crisis arised from the global banking crisis which stems from subprime mortgage credits and appeared first in the US and then affected almost all countries in the world (Batýrel, 2008;1). This crisis made worse the effects of Asia Crisis which the globe has not fully recovered from. Thus the world economy moved towards recession which is identified as fact of decreasing demand for raw materials, products and services (Shama; 1993). In the US and EU countries, a recession is identified as at least two quarters of a decrease in real GDP (Srinivasan et al, 2005;110) and recessions can firmly affect the performance of whole economic sectors (Cundiff, 1975; 2, Shama;1993;64, Srinivasan, Rangaswamy and Lilien, 2005; 109, and Quelch, 2008; 1).

The recession like other economic crises affects consumers' perceptions and behaviours (Kotler, 1973;43, Kelley and Schwee, 1975;45, Cundiff, 1975;1, Shama, 1978;46 , 1993;6 and Shapiro, 1985;28). Related literature stated that consumers change their perceptions, preferences and purchasing behaviours during economic downturn, in recession in particular (Shama, 1978;45, Ang et al , 2000;98, Ang, 2001;6 and Na et al, 2003;48). For this reason, marketers need to adjust their strategies according to these changing perceptions and behaviours (Shama, 1993;63).

During the recession, marketing function plays a crucial role in lots of decision areas (Cundiff, 1975;1). The decisions sometimes may be important for their survivals (Torlak, 2005;41) and sometimes to stay profitable and consumer-responsive (Shama, 1993;64) while some firms view the recession as an opportunity to develop (Srinivasan et al, 2005;110). This difference may be relevant with the insights of the companies regarding the recession or the company size and sector (Shama, 1993; 65). Eventually, it can be said that the recession may affect firms in a different size and sector and marketing decision makers get diverse strategic measures to adopt changes in economic milieu (Shama, 1993;63).

After all, this paper seeks to find out perceptions and responses of the marketing decision makers to the last global recession regarding the company size and sector in Turkey by measuring the followings: 
1.The meaning of the current economic situation after the 2009 Global Recession to marketing decision makers

\section{The effect of the recent recession on their marketing decisions}

3. Their adjustments in marketing strategy and activities regarding the global recession.

Another purpose of this paper is to make recommendations to marketing decision makers and whole economic players as well as marketing academicians. Performed the aims of this paper, the research will be a connection between the companies and scholarly marketing literature.

\section{LITERATURE REVIEW}

Some researchers defined the relationship between the recession and marketing related issues in the literature (Yang, 1964;26, Cundiff, 1975;1 and Coulson et al, 1980;99, Shama, 1993,63; Srinivasan et al, 2005;112, Quelch, 2008;1). Recession was defined as a situation in which the demand for a product is less than its previous level by Kotler (1973) and as decreasing demand for raw materials, products and services, including labour by Shama $(1978 ; 45)$. The next researches (Goodell and Martin, 1992;7, Shama, 1993;64) remarked again similar but limited issues of the recession and marketing relationship. Companies' various responses to the recession were also stated in Barwise's various studies (Barwise, 1999;10, Barwise and Styler, 2002;6).

Cundiff $(1975 ; 1)$ and Srinivasan et al $(2005 ; 112)$ stated that some companies fall down during recession while some others prosper and even develop. Various researches indicates that the firms investing during recession may get considerable benefits (McGraw-Hill Research, 2002; Strategic Planning Institute, 2002). Some researches reveal the results of proactive marketing strategies during economic downturn (Teece et al, 1997;512, Srinivasan, 2005;113). On the other hand, lots of firms severely reduce the marketing expenditures in economic downturn and firms may be also forced to fire some of their employees, or diminish wages (Cundiff, 1975;1).

During a recession, consumers are spending less and saving more of their income (Cundiff, 1975;1) and they become value-oriented (Quelch, 2008;1). There are many other researches indicating that consumers change their purchase behaviours regarding all marketing mix elements during economic distress (Shama, 1978;45 Milanova, 1999;426, Ang et al, 2000;99 Ang, 2001;7). There are several indicators which measure consumers' attitudes toward the economy as a whole and perceptions in particular. These measurements may differ according to the countries. The Survey Research Center's Consumer Centiment Index (CCI) and The Conference Board's Consumer Confidence Index (CCI) are two of them used in the US (Shama, 1993; 62). In Turkey, Consumer Confidence Index shows the general tendency of consumers toward economy.

As a reaction to these shifts, many changes also occured on the firm side. Quelch $(2008 ; 1)$ underlined eight factors four of which are maintaining marketing spending, adjusting product portfolio, supporting distributors and adjusting pricing tactics which firms should take into consideration during the recession. Besides, Bonoma (1991;10) recommended to marketing managers about the recession as marketing practices to avoid 'empty middle' marketing, not to mistake expansiveness so much, "do more for less and remember and what winter is like when summer again comes". It is specifically emphasized that marketers use considerable more coupons in marketing mix to battle the negative effects of the recession and well-planned promotion, product policies and quality are noteworthy issues for the firms during recession according to Cundiff $(1975 ; 1)$.

There are also important but limited researches about the recession and marketing relationship regarding company size and sector in the literature. A research reported that small companies are much more affected by recession (Feder, 1991;22, Torlak, 2005;43) and Shama cited from Bowers' (1991) journalistic literature that how small firms reduce their expenses in economic hardship. Torlak $(2005 ; 47)$ also stated that small firms should know how to adjust pricing, carrying out advertising policies and granting credit to customers. Marketing Sharpa (2008) examined TE Marketing during a downturn on the orher hand, reported that mid-size companies and manufacturing companies in particular, experience more hardship. Beyond these studies, Mandel $(1991 ; 60)$ and Shama $(1993 ; 65)$ who benefited from journalistic literatures of Pearlstein (1991), Stout (1990) and Nasar (1991) published in several journals investigated effects of recession in service sectors. 


\section{Recession in Turkey}

Recession was felt since the last quarter of 2008 in Turkey and recently a recovery is felt by various economic signals. The financial indicators confirmed that Turkish economy has been severely affected by the recession and then have just leant to rise again. The unemployment rate was recorded at $11,6 \%$ in January 2008 while the rate increased to $15,5 \%$ by January 2009 while decreased to $14,5 \%$ by January 2010 as well as Monthly Industry Production Index declined 20,9\% during February 2009 comparing with February 2008 and it increased again 18,1\% by February 2010 comparing with the last year (TurkStat). Table 1 also shows the fluctuation in GDP amounts from the first quarter of 2008 to the last quarter of 2009 in Turkey.

\section{Table 1: Gross Domestic Products for Eight Quarters in Turkey between the first quarter of 2008 and the fourth quarter of 2009 (in million dollars).}

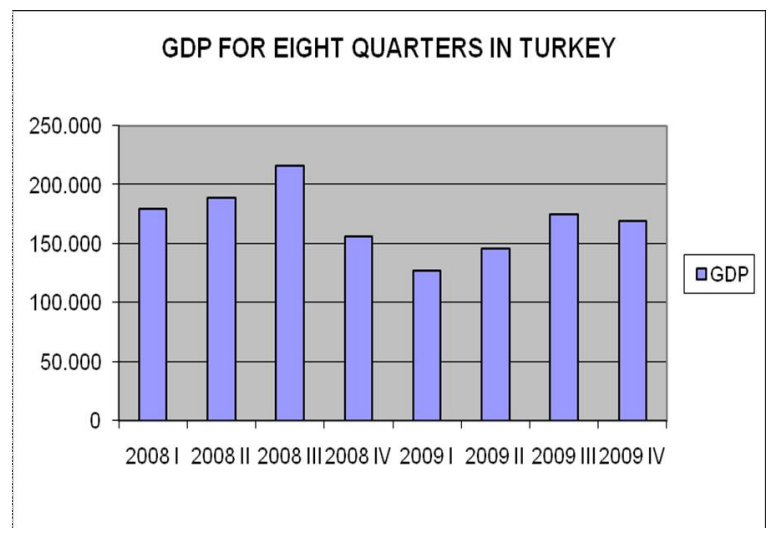

Source: TurkStat, http://www.tuik.gov.tr/PreHaberBultenleri.do?id=6219 (19.04.2010)

Table 2 reveals that consumer confidence index (CCI) decreased by June 2009 and increased by January 2010 in Turkey. This graph also confirms general tendency regarding consumers' common attitudes towards economy.

\section{Table 2: Consumer Confidence Index Between the March 2009 and the March 2010 in Turkey}

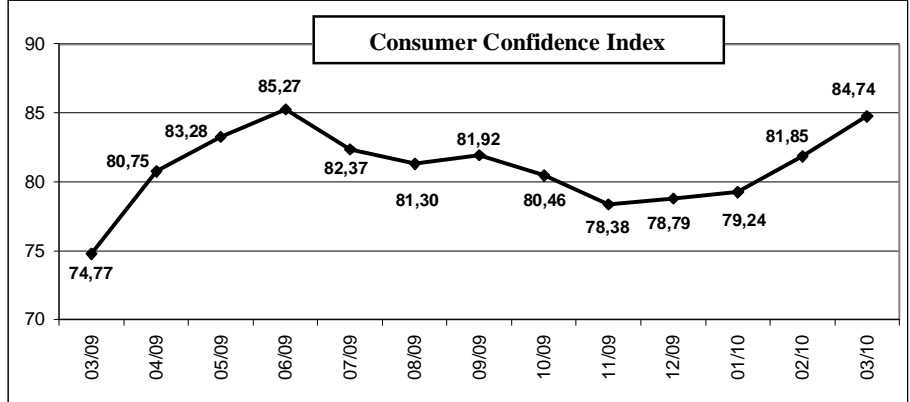

Source: TurkStat, http://www.tuik.gov.tr/PreTablo.do?tb_id=21\&ust_id=7 (19.04.2010)

Firms adjust their strategies in terms of consumers' attitudes and behaviours so it's expected that firms' general insights are in company with the fluctuation of general economic indicators.

\section{Company-Size Level}

Companies with different size may face different economic environments depending on their target markets and market power. Larger firms usually have more market power which may help them whather the economy has bad effects on their functions (Shama, 1993:67). However, a small business 
might have a small market niche which can protect it during a recession while other small firms unable to borrow needed cash. Shama $(1993 ; 67)$ examined the journals of Feder and Bowers in his study. Feder (1991) stated that especially small businesses are affected in the recessionary milieu, and Bowers (1991) stated how small firms are reducing their expenses in their journals. On the other hand, MarketingSherpa examined TE issue of marketing during a downturn via a research carried out by itself (MarketingSherpa, 2008). It was surveyed whether the marketing budget and effect of downturn is changed in response to the economy through company size in MarketingSherpa Survey, 5;11).

Torlak (2005;41) emphasized that recssions initially become a threat for small firms regarding their scales and they should know to adjust pricing, advertising, selling promotions and granting credit to customers.

Shama (1993) reported that marketers in small firms and large firms perceive the economic situation differently. According to his findings, perception of economic conditions and perceived impact of economic climate as well as adjustments to the changing conditions vary by firm size.

\section{Sector Level}

The theory about sector-level studies is that different sectors may be experiencing different economic climates in the same economic milieu. Service sectors generally have been seen as developing sectors for many years. However, Shama $(1993 ; 65)$ reported that the service sectors are also in recession referring to journals of Nasar (1991) and Stout (1990).

Nasar (1991) stated that the service sector in the United States initially regarded as an engine for new jobs, is undertaking a wide cutting back, much as the industry sector did in the former decade. According to Nasar, such a cutting back characterizes service firms in retailing, financial services, accounting, real estate, and temporary help. Mandel (1991;61)also differentiated different service sectors, stating development in some firms and decrease in other firms. Pearlstein (1991) examined the recession in the financial sector as an example of recessionary pressure in the service sector.

Shama $(1993 ; 66)$ studied wheather the marketers perceive the economic conditions and adjust their marketing activities differently in terms of their sector. He found out that there's significant difference between firms for perception of recent economic climate, perceived impact and adjustments in marketing activities in terms of firm size. Additionally, service firms are differentiated from industry firms regarding especially promotional appeal, spending relatively more on printed media, adding more distribution channels increasing market segmentation efforts, diversifying and reducing labour force.

To this end, in this study we constructed our hypotheses as:

H1: The subjective meaning of 2009 recession to marketing decision makers vary by company size, as small and large, and sector in Turkey.

H2: The perceived impact of the economic environment of 2009 recession on marketing managers vary by company size, as small and large, and sector in Turkey.

H3: The arrangements of marketing managers out of 2009 recession vary by company size, as small and large, and sector in Turkey.

\section{RESEARCH METHOD}

\section{Sample}

To test the hypotheses of this study, three samples of marketing decision makers in different sectors and different size companies were surveyed. There are three sample groups which are large industry firms, large service firms and small firms and their populations can be seen below:

Sample 1: 60 randomly selected companies from Fortune 500: Large industrial firms

Sample 2: 40 randomly selected companies from Fortune 500: Large service firms

Sample 3: 60 randomly selected small business companies from KOBINET list: Small firms 
Large industrial and service firms are selected from Fortune 500 Turkey list. KOBİNET includes the list of small and mid-size companies so small firms are selected from KOBINET list.

\section{Procedure}

In this study, a scale developed by Shama (1993) was used. The scale including mostly close-end, Likert-scaled questions about the meaning of the present economic environment to them, the impact of this environment on their firms and their marketing activities and their responses to the perceived economic milieu. Particular questions measuring the affect of and adjustments to recession were constructed, based on marketing literature (Kotler 1973, Shama 1978 and Shapiro 1985). There were totally 31 questions, 29 of which are Likert-scaled questions.

The scale was initially translated into Turkish then translated into English again in order to eliminate translation problems. Pair of marketing academicians were surveyed to control the comprehensibility of the expressions in the questions. Marketing managers were contacted by e-mail and follow-up phone calls to make sure of their cooperation in this study. Marketing managers agreeing to participate to the survey answered the questionnaire form.

The study reflects 59 percent response rate (95 marketing managers are divided by the total 160 marketing managers). For the subsamples, 30 marketing managers of total 60 managers in industry sector, 30 marketing managers of 40 managers in service sector and 35 marketing managers of 60 managers in small firms were responded in the survey.

\section{Analyses}

Nonparametric tests would be most appropriate tests for the first two hypotheses of the study that will examine how the marketing managers describe the present economic environment as their companies is concerned and what the impact of the environment is on their companies. There are 6 choices for the first question and three choices for the second one as positive, neutral and negative. KruskalWallis Test was performed to analize the difference between three groups which are large industury, large service and small firms. Analysis of variance, ANOVA, was also performed for the Likert type questions for a parametric test.

\section{RESEARCH FINDINGS}

Table 3 presents the perceptions of marketing managers $\{\mathrm{N}=95$ ) of the nature of the economic environment by sector. There's a clear difference between small firms and large firms while the responses of the managers do not differ by sector.

\begin{tabular}{|c|c|c|c|}
\hline \multicolumn{4}{|c|}{$\begin{array}{l}\text { Table 3: Marketing Decision Makers' Perception of the Economic Environ- } \\
\text { ment (Total sample, } \mathrm{N}=95 \text {, in percentage) }\end{array}$} \\
\hline $\begin{array}{l}\text { How would you describe the present economic environment inso far } \\
\text { as your company is concerned? (In percent) }\end{array}$ & Industry & Service & Small \\
\hline Growth & $18(60 \%)$ & $18(60 \%)$ & $17(48 \%)$ \\
\hline Recession & \begin{tabular}{|ll}
3 & $(10 \%)$
\end{tabular} & $2(7 \%)$ & $2(6 \%)$ \\
\hline Depression & $1 \quad(3 \%)$ & $3(10 \%)$ & $3(9 \%)$ \\
\hline \begin{tabular}{|l|} 
Stagnation \\
\end{tabular} & $\begin{array}{|ll|}8 & (27 \%)\end{array}$ & $5(16 \%)$ & $13(37 \%)$ \\
\hline Inflation & & $2(7 \%)$ & \\
\hline \multicolumn{4}{|l|}{ Other } \\
\hline TOTAI & 30 & 30 & 35 \\
\hline
\end{tabular}

In Table 4, marketing decision makers' perceptions of the impact of the economic environment on their companies are given. There's again no significant difference between indusrty and service sectors. However, small firms seem more pesimistic regarding the impact of the environment on their companies. 
Table 4: Marketing Decision Makers' Perception of the Impact of the Economic Environment on their companies (Total sample, $\mathrm{N}=95$, in amount and percentage)

\begin{tabular}{|l|l|l|l|l|}
\hline $\begin{array}{l}\text { What has the impact of the environment been on your company? (In } \\
\text { amount and percent) }\end{array}$ & Industry & Service & Small \\
\hline Positive & $13(43 \%)$ & $13(43 \%)$ & $6(17 \%)$ \\
\hline Neutral & $6(20 \%)$ & $7(23 \%)$ & $12(34 \%)$ \\
\hline Negative & $11(37 \%)$ & $10(34 \%)$ & $17(49 \%)$ \\
\hline \multicolumn{2}{r|}{ TOTAL } & 30 & 30 & 35 \\
\hline
\end{tabular}

Table 5 and Table 6 present the results of ANOVA analyses. Table 5 indicates the means of the sector groups in terms of their responses to the questions about how much the present environment influenced their marketing strategies. Specific differences seem between the companies regarding company's size and sector. Similarly, Table 6 presents the means of the sector groups regarding marketing managers' responses to the economic environment.

\section{Tablo 5: The Results of Kruskal-Wallis Test for the First Question About the Description of the Marketing Managers the Economic Environment}

\begin{tabular}{|l|c|}
\hline \multicolumn{2}{|c|}{ Test Statistics $^{\mathbf{a}, \mathbf{b}}$} \\
\hline \multicolumn{2}{|c|}{} \\
\hline Chi-Square & VAR00002 \\
\hline df & 2,288 \\
\hline Asymp. Sig. &, 525 \\
\hline $\begin{array}{l}\text { a. Kruskal Wallis Test } \\
\text { b. Grouping Variable: VAR00001 }\end{array}$ \\
\hline
\end{tabular}

Table 6: The Results of KruskalWallis Test for the Second Question About the Impact of the Economic Environment on Companies

\begin{tabular}{|l|c|}
\hline \multicolumn{2}{|c|}{ Test Statistics $^{\text {a,b }}$} \\
\hline \multicolumn{2}{|c|}{} \\
\hline Chi-Square & SORU2 \\
\hline df & 2,065 \\
\hline Asymp. Sig. &, 079 \\
\hline $\begin{array}{l}\text { a. Kruskal Wallis Test } \\
\text { b. Grouping Variable: KOD }\end{array}$ \\
\hline
\end{tabular}

The results of Kruskal Wallis Test is given in Table 5 for the answers of the first question. Kruskal Wallis is a nonparametric alternative test of ANOVA. Since the data on the first question is not parametric and there are more than two independent samples, Kruskal-Wallis is the best choice to analize the answers of the second questions. According to the test results, there's no significant difference $(p \leq, 05)$ between the three sectors regarding their descriptions of the economic environment as their companies are concerned. For this reason, the subjective meaning of 2009 recession to marketing decision makers does not vary by company size, as small and large, and by sector in Turkey which is contrary to the previous literature. Therefore, $\mathrm{H} 1$ is not supported.

\section{Table 7: Results of ANOVA: The Impact of the Economic Environment on Specific Marketing Decisions}

\begin{tabular}{|l|l|l|l|l|l|}
\hline $\begin{array}{l}\text { Overall, how much has the present environemt in- } \\
\text { fluenced your..... }\end{array}$ & Industry & Service & Small & F-Ratio & Sig \\
\hline Competitive strategy & 4,05 & 3,70 & 3,65 & 1,880 &, 158 \\
Marketing strategy & 4,37 & 4,26 & 4,11 &, 232 &, 793 \\
Consumer credit policies & 3,83 & 3,96 & 3,85 &, 972 &, 382 \\
Selection of target customers & 2,93 & 3,20 & 2,68 & 1,646 &, 198 \\
Pricing decisions & 4,13 & 4,16 & 4,37 &, 601 &, 550 \\
New product introduction & 3,62 & 3,76 & 3,74 &, 680 &, 509 \\
Promotion budget & 4,17 & 3,73 & 3,68 & 1,413 &, 249 \\
Promotional (advertising) appeal & 4,03 & 4,13 & 3,57 &, 605 &, 548 \\
Sales employees & 2,41 & 2,43 & 2,97 & 4,979 &, 009 \\
Selection of promotion media & 3,37 & 2,66 & 2,40 & 7,654 &, 001 \\
Public relations & 2,34 & 2,76 & 2,02 & 11,906 &, 000 \\
R\&D budget & 2,13 & 2,53 & 3,31 & 5,370 &, 006 \\
Distribution of your product(s) or service(s) & 1,53 & 1,94 & 2,877 &, 061 \\
\hline
\end{tabular}


The result of Kruskal Wallis Test is given for the answers of the second question in Table 6. According to the test results, there's no significant difference between the three sectors regarding their responses given to the second question which searches the impact of the economic environment on their companies. Namely, the perceived impact of the economic environment of 2009 recession on marketing managers does not vary by company size, as small and large, and by sector in Turkey so H2 is not supported.

According to the results of ANOVA tests, the marketing managers in the three different groups of companies vary regarding influence degree of present economic environment to their companies in terms of sales employees, selection of promotion media, public relations and Research and Development budget issues. Marketing managers in large companies state that present economic environment selection of promotion media and public relations. However, small firms state that present economic environment sales employees and research and development budget significantly different from the other sectors.

\begin{tabular}{|c|c|c|c|c|c|}
\hline \multicolumn{6}{|c|}{$\begin{array}{c}\text { Table 8: Results of ANOVA: Marketing Managers' Response to the Economic } \\
\text { Environment }\end{array}$} \\
\hline $\begin{array}{l}\text { To what extent did your company engage in each of the following } \\
\text { measures in response to the present environment? }\end{array}$ & Industry & Service & Small & F-Ratio & Sig \\
\hline $\begin{array}{l}\text { Changed marketing strategy } \\
\text { Increased strategic planning efforts } \\
\text { Loosened customer credit } \\
\text { Modified target markets } \\
\text { Used more price incentives } \\
\text { Added new products or product lines } \\
\text { Pruned some product lines or products } \\
\text { Increased promotional budget } \\
\text { Changed promotional appeal } \\
\text { Used more sales promotion } \\
\text { Spent relatively more on radio and print ads } \\
\text { Reduced R\&D budget } \\
\text { Added more distribution channels } \\
\text { Increased market segmentation efforts } \\
\text { Diversified into other products or businesses } \\
\text { Reduced labor forcce }\end{array}$ & $\begin{array}{l}4,03 \\
4,55 \\
3,73 \\
2,85 \\
3,63 \\
2,53 \\
2,55 \\
3,34 \\
3,83 \\
3,53 \\
2,83 \\
2,24 \\
1,72 \\
2,37 \\
2,05 \\
2,17\end{array}$ & $\begin{array}{l}3,70 \\
4,16 \\
3,43 \\
2,96 \\
3,53 \\
1,76 \\
1,76 \\
2,16 \\
2,66 \\
3,20 \\
1,86 \\
2,26 \\
1,53 \\
2,13 \\
1,90 \\
1,80\end{array}$ & $\begin{array}{l}3,85 \\
4,02 \\
4,11 \\
2,62 \\
4,20 \\
1,40 \\
2,17 \\
1,65 \\
2,22 \\
3,77 \\
1,88 \\
2,91 \\
1,22 \\
1,62 \\
1,97 \\
2,42\end{array}$ & \begin{tabular}{|l}
1,195 \\
2,773 \\
4,155 \\
1,155 \\
3,004 \\
16,783 \\
7,168 \\
23,361 \\
13,348 \\
2,126 \\
11,018 \\
4,872 \\
5,593 \\
4,774 \\
, 190 \\
3,491
\end{tabular} & \begin{tabular}{|l}
, 307 \\
, 068 \\
, 019 \\
, 320 \\
, 054 \\
, 000 \\
, 001 \\
, 000 \\
, 000 \\
, 125 \\
, 000 \\
, 010 \\
, 005 \\
, 011 \\
, 827 \\
, 035
\end{tabular} \\
\hline
\end{tabular}

Marketing managers also vary in terms of their response to the changing economic environment. Marketing managers in small firms have much more tendency to loosen customer credits while the marketers in service firms are not reluctant for this. On the other hand, large industry firms positively look at adding new product or product lines as well as prun some product lines or products while the marketing managers in small companies don't. Additionally, the marketing managers increase their promotional budget and change the promotional appeal significantly much more than the marketers in small companies. Marketing managers in large industry companies spend much on printed advertisement and increase their market segmentation efforts comparing with the service firms and small firms. On the other hand, small firms reduce their research and development expenses and reduce their labour force relatively. For this reason, H3 is partially supported.

\begin{tabular}{|c|c|c|}
\hline \multicolumn{3}{|c|}{ Table 9: Result of Reliability Analysis } \\
\hline \multicolumn{3}{|c|}{ Reliability Statistics } \\
\hline Cronbach's Alpha & $\begin{array}{c}\text { Cronbach's Alpha } \\
\text { Based on Standardized } \\
\text { Items }\end{array}$ & N of Items \\
\hline, 935 &, 937 & 29 \\
\hline
\end{tabular}

For evaluating the internal consistency of the present study, reliability analysis was performed based on the Cronbach Alpha coefficient Method. As known, the minimum value of Alpha coefficient is expected to be 0,7 on descriptive research (Hair et al, 1998). The results in Table 9 indicate that the level of internal consistency of this study is satisfactory, with 93 percent.

\section{CONCLUSION AND DISCUSSION}

The last global economic recession severely affected the whole world and Turkey in particular. Consumers' attitudes and behaviours change during economic hardship including recessionary climate. 
Many reseraches confirm that consumers have different purchasing behaviours in a recession and several economic indicators like Consumer Confidence Index support this insight.

Marketing strategies play a key role during recession periods and other economic crises. Marketers should adjust their companies' marketing strategies to the changing economic milieu. However, their descriptions of present economic conditions and perceptions about the impact of the economic climate on their companies may not be similar in terms of company size and sector. Former studies reveal that there are significant differences between the companies' marketing strategies during economic hardship in terms of their size and sector type.

This study examined how marketing managers perceive the present economic conditions regarding as their company, what the effects of it on companies as positive, negative or neutral and what kind of marketing policies they apply and the responses vary according to the company size and sector.

Findings don't fully support the study's hypotheses. under the present economic conditions in Turkey, according to the answers of 95 participants, more particularly, findings are that:

1. The meaning of the present economic conditions to marketing managers doesn't depend on company size and economic sector.

2. The perceived impact of the economic environment doesn't vary with the size of the company and by economic sector.

3. The marketing managers in the three different groups vary regarding the influence degree of present economic environment on their companies in terms of sales employees, selection of promotion media, public relations and R\&D budget issues.

4. Marketing managers in large companies stated that selection of promotion media and public relations is relatively much more affected by the present economic environment.

5. Marketing managers in small firms state that they have been relatively so much influenced by the present economic environment through their sales employees and $R \& D$ budget.

6. Marketing managers in small firms have much more tendency to loosen customer credits while the marketing managers in service firms are not reluctant for this.

7. Large industry firms positively look at to add new products or product lines as well as prun some product lines or products while small firms don't.

8. Large industry firms increase their promotional budget and change promotional appeals significantly much more than small companies do.

9. Marketing managers in large industry companies spend much on printed advertisement and increase their market segmentation efforts comparing with the service firms and small firms do.

10. Small firms diminish their $R \& D$ expenses and reduce their labour force much more than large firms.

As a result, it can be said that marketing managers in large industry firms, service firms and small firms perceive the influence of the present economic environment different from each other. Similarly, there's again no significant difference among their perceptions of general economic environment regarding their firms. However, there are some significant differences especially between small firms and large firms regarding influence of the economic environment on specific marketing decisions and their adjustments to the economic environment.

Large firms with broader financial sources may act more independently. Because they especially don't cut back their R\&D budget, they can invest in new products or product lines. Besides, they don't diminish promotional budget in economic hardship so they may enjoy benefit. On the other hand, small firms cut back their costs, R\&D and human resources in particular during economic downturn. They actually may go collaboration with other small firms to profit from scale economy and then they may invest in new products, services not to lose competitive strategy with the larger firms during economic downturn. Additionally, they may seek for niche markets as opportunity, to which large firms do not pay attention or miss. Small firms may go on their activities in such market areas as a way to survive and stay profitable during economic hardship. 


\section{REFERENCES}

Ang, Swee Hoon, Leong Siew, Meng and Kotler, Philip (2000), The Asian Apocalypse: Crisis Marketing for Consumers and Businesses, Long Range Planning, 33, pp.97-119.

Ang, Swee Hoon (2001), Personality Infuelnces on Consumption: Insifht from the Asian Economic Crisis, Journal of International Marketing, 13 (1), pp.5-19.

Barwise, Patrick (1999), Advertising in a Recession: The Benefits for the Long-Run, NTC Publications, UK.

Barwise, Patrick and Styler, Alan (2002), Marketing Expenditure Trends, London Business School / HAVAS Marketing Report, London, UK.

Batırel, Ömer Faruk (2008), Global Ekonomik Kriz ve Türk Kamu Maliyesi, Ýstanbul Ticaret Üniversitesi Sosyal Bilimler Dergisi, 7 (13), pp.1-9.

Bowers, Brent ( 1991), New Business Owners are Pinching Pennies This Year, Wall Street Journal, 27 December, A8.

Coulson, Andrew J.; Mauser, Ferdinand F.; Holloway, Roberst J., Lazer, William and Gross, Irwin (1980), Marketing Issues, Journal of Marketing, 44 (4), pp.97-102.

Cundiff, Edward W. (1975), What is the Role of Marketing in a Recession?, Journal of Marketing, 39, p.1.

Feder, Barnaby J. (1991) For Small Concerns, a Tougher Row: Hard Times for Small Busi,ness", New York Times (18 February)

Goodell, P. W. and Martin, C. L. (1992), Marketing Strategies for Recession Survival, Journal of Business and Industrial Marketing, 7(2), pp.5- 16.

Hair, Joseph H.; Black Bill, Babin, Barry; Anderson, Rolph E. And Tatham, Ronald L. (1998) Multivariate Data Analysis,Prentice Hall, USA

Kelley, Eugene, J. and Schwee, L. Rusty (1975), Buyer Behaviours in a Stagflation/Shortages Economy, Journal of Marketing, 39, pp.44-50.

Kotler, Philip (1973), The Major Tasks of Marketing Management, Journal of Marketing, 37, October, pp.42-49.

Mandel, Michael, J.(1991), There's a Silver Lining in the Service Sector, Business Week, Industrial/ Technological Edition, March, pp.60-61.

MarketingSherpa Special Report (2008), Marketing During a Downturn, Warren, USA, http:// www.SherpaStore.com

McGraw-Hill Research (2002), http://www.mcgrawhill.com

Milanova, Elena (1999), Consumer Behaviour, Advances in Consumer Research, 26, pp.424-430.

Na, Woonbong; Son, Youngseok and Marshall, Roger (2003), Purchase-Role Structure in Korean Families: Revisited, Psychology\&Marketing, 20 (1), pp.47-57.

Nasar, Sylvia (1991), Unexplored Territory. A Recession in Services, New York Times, 3 February, A1.

Pearlstein, Steven(1991),Service Industries Face Hard Times Amid Corrections, Washington Post, 13 August, C1. 
Quelch, John (2008), Marketing Your Way Through a Recession, Harward Business School Working Knowledge, March 3, pp.1-2.

Shama, Avraham (1978), Management and Consumers in an Era of Stagflation, Journal of Marketing, July, pp.43-52.

Shama, Avraham (1993), Marketing Strategies During Recession: A Comparison of Small and Large Firms, Journal of Small Business Management, July, pp.62-72.

Shapiro, Benson (1985), Rejuvenating the Marketing Mix, Harvard Business Review, 5, SeptemberOctober,pp.28-29.

Srinivasan, Raji; Rangaswamy, Arvind and Lilien, Gary L. (2005), Turning Adversity into Advantage: Does Proactive Marketing During a Recession Pay Off?, International Journal of Research in Marketing, 22, pp.109-125.

Stout, Hillary (1990), Slowdown Spreads to the Service Sector, Wall Street Journal, 10 September, A2.

Strategic Planning Institute (2002), Advertising in a Recession.,http://www.spi.com

Teece, D. J.; Pisano, G. and Shuen, A. (1997), Dynamic Capabilities and Strategic Management,. Strategic Management Journal, 18, (7), pp.509- 533.

Torlak, Gökhan N.(2005), Effective Management of Marketing Strategies in Small Firms, Journal of Academic Studies, 24, pp.41-56.

TurkStat, http://www.tuik.gov.tr/PreHaberBultenleri.do?id=621 (19.04.2010)

http://www.tuik.gov.tr/PreTablo.do?tb_id=21\&ust_id= (19.04.2010)

Yang, C. Y.(1964), Variations in the Cyclical Behavior of Advertising. Journal of Marketing, 28, April, pp.25- 30 . 